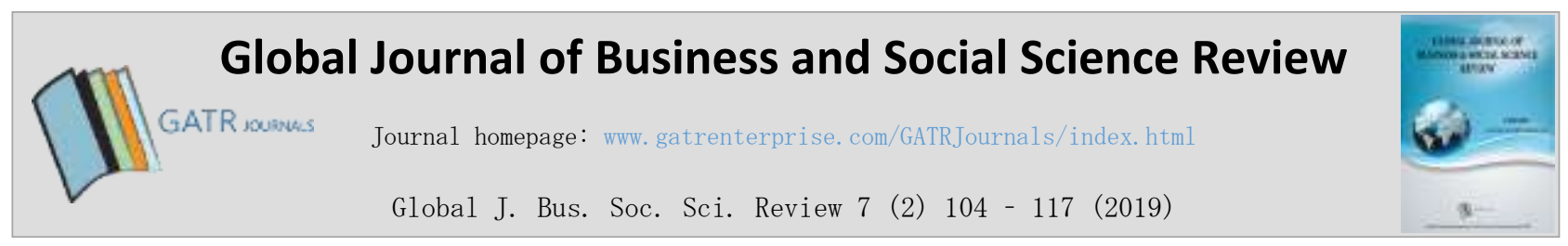

\title{
The Construction of Entrepreneurial Accounting: Evidence from Indonesia
}

\author{
Hanif Hanif, ${ }^{*}$ Abdulah Rakhman, ${ }^{2}$ Muhammad Nurkholis ${ }^{3}$ \\ ${ }^{\text {a,b,c }}$ Kwik Kian Gie School of Business, Jl. Yos Sudarso Kav. 87, 14350, Jakarta, Indonesia
}

\begin{abstract}
Objective - This research aims to identify a cultural theme embedded in entrepreneurial accounting and construct the form of entrepreneurial accounting.

Methodology/Technique - A cognitive anthropology method is employed in this research to investigate the cultural atmosphere of entrepreneurial accounting. This is achieved by conceiving the atmosphere into informants' (owner/entrepreneur-director) mind-set. The research was conducted at various Padang restaurants in Jakarta, Indonesia, that were classified into four groups based on their size and level of complexity.

Finding and Novelty - Firstly, a number of cultural themes of entrepreneurial accounting are revealed among the four Padang restaurant groups. There are four similar cultural themes: (a) business process turbulence; (b) togetherness intensity; (c) informal control processes; and (d) formal control processes. Despite the fact that all of the restaurants have similar cultural themes, the elements embedded in each theme are different and require certain adjustments in the design of entrepreneurial accounting based on a profit sharing system. Secondly, a construction of entrepreneurial accounting coloured with a unique socio-cultural background was also discovered. This construction enables owner/entrepreneur-directors to execute work programs with a view to achieving the company's goal to enhance performance, either financially or non-financially.
\end{abstract}

Type of Paper: Empirical.

Keywords: Socio-Culture; Performance; Entrepreneurial Accounting; Control; Cognitive Anthropology.

Reference to this paper should be made as follows: Hanif, H.; Rakhman, A.; Nurkholis, M. (2019). The Construction of Entrepreneurial Accounting: Evidence from Indonesia, Global J. Bus. Soc. Sci. Review 7 (2): 104 - 117. https://doi.org/10.35609/gjbssr.2019.7.2(1)

JEL Classification: M41, M49.

\section{Introduction}

The idea to construct entrepreneurial accounting stems from the notion that organizational control is a social process (Anthony \& Govindarajan, 2007). Hence, a controller (owner/entrepreneurial-director) must have a sense of leadership, social skills, and a sense of entrepreneurship to control the business. This idea is supported by the fact that the control process adjusts with the environment (Hayes, 2014).

\footnotetext{
* Paper Info: Revised: March 11, 2019

Accepted: June 23, 2019

* Corresponding author: Hanif Hanif

E-mail: Hanif.ismail@kwikkiangie.ac.id

Affiliation: Kwik Kian Gie School of Business, J1. Yos Sudarso Kav. 87, 14350, Jakarta, Indonesia
} 
This requires the owner/entrepreneur-director to have a sense of leadership and a proactive nature, to bring about innovation. Meanwhile, Kets de Vries (1996) notes that entrepreneurship is linked with the need for control, a sense of distrust, a desire for applause, and resort to primitive defence mechanisms.

This means that entrepreneurship has been studied in relation to management accounting which is considered important to entrepreneurial accounting. The rationale for studying the cultural atmosphere of entrepreneurial accounting is the relationship between control (management accounting) and organizational culture. Collier (2005) states that social culture elements can cause subtle shifts in power and hence are able to buffer and modify the influence of formal, systems-based forms of control.

One study that explores the relationship between accounting and entrepreneurship is research by Toms (2006) which emphasizes the change of varied accountability structures toward behavioural patterns of entrepreneurial learning. Collier (2005) reveals how an owner-director taking a position as an entrepreneur controls management through social control towards employees in order to enable them to suitably execute strategies to enhance performance.

This construction of entrepreneurial accounting may allow entrepreneurship to rapidly develop because entrepreneurship is at the heart of economic growth. Entrepreneurs are important to foster economic growth by creating jobs and increasing economic output (Toms, 2006). Entrepreneurship has a positive impact on the microeconomics and macroeconomics of a country (Minniti \& Lévesque, 2008). Entrepreneurship is not easy, and requires reliance on individual characters (DJankov et. al., 2006). Whether an individual is able to become an entrepreneur and create a successful business depends on their personality and existing cognitive abilities (Baron, 1998).

The ability to conduct cost and benefit analysis is crucial in the realm of management accounting (Hilton, 2008; Hansen \& Mowen, 2005), and is regarded as one activity of entrepreneurial accounting. There are other calculations and analysis that an entrepreneur performs such as management accounting. This proves an important link between entrepreneurship and accounting, known as entrepreneurial accounting (Hanif, 2015c).

Management accounting is flexible and has no standardization in its analysis and reporting. Hence, management accounting is open for modification. Owners/entrepreneur-directors may use their influence to create the required internal accounting by using the company's socio-culture in an attempt to create an internal accounting system to foster harmony between economic interest and the company's goals.

Collier (2005) and Hanif (2015b) note that a company's socio-culture can colour the process of management within the company. The terminology for "entrepreneurial accounting" was introduced by Hanif (2015c) in his research that investigates the meaning beyond a particular accounting practice in an entrepreneurial activity among Padang restaurants. Unfortunately, this research did not identify a complete construction of entrepreneurial accounting. Further research is needed to incorporate the cultural root of the society in which the entrepreneurial actors have been raised.

A cognitive anthropology method is employed in this study to reveal the meaning of entrepreneurial accounting in its cultural root. It is assumed that the portrayal of an individual's cultural atmosphere lies in the people's cognition (Spradley, 1979). This differs from that of entrepreneurship by Hanif (2015c) which employs a phenomenological method. It is expected that the research using the ethnography method develops a more established and comprehensive construction of entrepreneurial accounting.

There is a slight difference in this research from that of Hanif (2015c) with respect to the onsite observation object. The observation process of the latter was only conducted in a Sederhana Padang Restaurant Group (SPRG) whereas this research observes not only SPRG but also others i.e. Kebumen Community Padang Restaurant (KCPR), Minang Raya Group (MRG), and Pagi Sore Pak Nojo (PSPN). This research was conducted at four different Padang restaurant groups to observe the different construction of entrepreneurial accounting implemented in each location, with a particular focus on these particular factors: business size, socio-culture, and business complexity. 
Based on the explanation above, the research question is formulated as follows: (1) How is entrepreneurial accounting interpreted by the community of the four Padang restaurant groups? (2) What is the construction of entrepreneurial accounting?

\section{Literature Review}

\subsection{Entrepreneurship}

A discussion about entrepreneurship cannot go far beyond a discussion about an entrepreneur as the actor. An entrepreneur is a person who acts in the field of entrepreneurship and has an ability to identify, select and create new business opportunities. Ardichvili et. al., (2003) points out that an entrepreneur has a natural sense of creating a business opportunity through development and evaluation on what he or she has performed. An entrepreneur must certainly be able to conduct cost and benefit analysis as well as evaluation in order to create opportunity. The cost and benefit analysis is conversely a skill embedded within the heart of the entrepreneurs, even though it is poured into a general scheme, less detailed even only in the portrayal of the mind (memory accounting).

In addition to a sense of calculation and analysis, Sexton and Bowman (1985) indicate that the uniqueness of an entrepreneur is that he or she can tolerate ambiguity and uncertainty. Future uncertainty is considered normal to an entrepreneur.

Entrepreneurship in a comprehensive horizon. Duane Ireland and Webb (2007) state that strategic entrepreneurship describes an owner/entrepreneur-director's efforts to collectively utilize the existing company's competitive excellence while exploring new innovation that will create competitive excellence in the future. The model is described by Duane Ireland and Webb (2007) as a unique construction by which the owner/entrepreneur-director manages to create wealth. The dimensions of the model start with an interaction of entrepreneurial mindset and culture that generates entrepreneurial leadership. Entrepreneurial leadership leads itself to a strategic management of resources and creativity for new innovation in an attempt to grab a competitive advantage that will eventually generate revenue and create wealth.

\subsection{The Role of Entrepreneurial Economics}

The advancement and regression of a country considerably depend on its entrepreneurial success. The more entrepreneurial activity, the more jobs are created which leads to greater economic growth. In this regard, Schumpeter, an economist, states that entrepreneurship is a key determinant of a economy's technological performance (Michelacci \& Silva, 2007).

Minniti and Lévesque (2008) suggest that there are more open questions to discuss in relation to entrepreneurship, for instance: how far does entrepreneurship contribute to economic growth? Are all types of entrepreneurial activities able to support the economic growth?

Indeed, economists have long been interested in observing the entrepreneurship. Minniti and Lévesque (2008) state that an Ireland economist, Richard Cantilon, initiated these observation by defining entrepreneurship as an individual will to make a practice of economy in order to make profit from pricing found differently between two financial markets involving financial risks. More economists have appeared to analyze entrepreneurship with a focus on entrepreneurial behavior (Minniti \& Lévesque, 2008).

\subsection{Entrepreneurship and Accounting}

The previous sections of this paper have explained that an entrepreneur is able to select and create new business opportunities. Those business opportunities might not be decided as one that promises benefit for future endeavor unless the entrepreneur has an ability to "read" its potential. The ability to conduct a cost and benefit analysis has been widely studied with respect to management accounting and control (Anthony \& 
Govindarajan, 2007; Hilton, 2008; Hansen \& Mowen, 2005; Blocher et. al., 2013). The "interface" of cost and benefit analysis possessed by an owner/entrepreneur-directors indicates the concept of entrepreneurial accounting.

On the other hand, an owner/entrepreneur-director is also able to engineer an innovative accounting system for a company, for example, in managing its' human resources to increase human productivity to build the company's wealth. Collier (2005) states that the owner/entrepreneur-director should adopt a sociocultural approach to manage their employees that will result in an approach known as mato based profit sharing which is used to increase employee productivity in a restaurant (Hanif, 2015a, 2017; Hanif et. al., 2018). Hanif et. al., (2013, 2015), and Hanif (2017) suggest that mato means a load or a point. Mato is used in the management of Padang restaurants. Such management does not allow the employees and managers to receive monthly fixed wage and salary; instead, they receive fluctuating income on the basis of profit sharing in a particular period. All managers and employees are given a load or a kind of personal scorecard called mato. The mato one receives represents his or her right to the profit shared. The workers' income or the managers' is proportionally equal with the value of the mato one owns, which is measured using numbers.

\section{Research Methodology}

Where does a culture of a society lie? It lies in the minds of its' people. The examination of an individual's mind is known as cognitive anthropology (Spradley, 1979). Is cognitive anthropology similar to cognitive psychology? Is it totally distinctive? Cognitive psychology is focused on the mind system of an individual whilst cognitive anthropology focusses on the mind system of a society in relation to people's life experiences (Bender et. al., 2010). D'Andrade (1981) suggests that an interface exists between cognitive anthropology and cognitive psychology. Both cognitive concepts emphasize the interaction between processing and information. However, cognitive anthropology aims to identify how cultural information is constrained and shaped by the way the brain processes information. Meanwhile, cognitive psychology aims to determine how the machinery of the brain works with all types of information, including cultural information.

Cognitive anthropology defines culture as a system of knowledge humans acquire through a learning process through which they interpret the world around them and set behavioral strategies to deal with it (Spradley, 1979). This cognitive anthropology approach is used to examine the culture of entrepreneurial activities occurring in the community of Padang restaurants in Jakarta, Indonesia. Cognitive entrepreneurial accounting is consistent with the concept of entrepreneurial cognition (Baron, 1998). The researcher therefore unearths the cultural atmosphere of entrepreneurial accounting to be conceived into the minds of the community.

Since the main actors in an organization have a strong influence on the form of the organizational culture of the company (Efferin \& Hopper, 2007; Hanif, 2015b), this research focusses on the "culture" of entrepreneurial accounting in the minds of the main actors. The "cultural atmosphere" of entrepreneurial accounting is explored in the minds of the informants to construct the concept of entrepreneurial accounting.

This research was conducted in four Padang restaurant groups. First, the Sederhana group is referred to as SPRG. Second, Kebumen community group is referred to as KCPR. Third, Padang Minang Raya group is referred to as MRG. Fourth is a group with no branches, which is referred to as PSPN. The data is collected using: (1) ethnographic records, being the result of onsite observations; (2) relevant artefacts, documents, transactions, and financial statements; and (3) in-depth interviews with informants. The informants are those with the most influence on the operation of the organization, namely, the owners, entrepreneurs and chief directors of the business groups (owner/entrepreneur-director). 


\section{Results}

The following table shows the cultural themes of entrepreneurial accounting and their elements which are classified according to the business groups of the Padang restaurants, namely SPRG, KCPR, MRG, and PSPN.

Table 1. Cultural Theme of Entrepreneurial accounting for respective business groups of Padang Restaurant

\begin{tabular}{|c|c|c|c|c|c|}
\hline \multirow{3}{*}{$\begin{array}{l}\text { Padang } \\
\text { Restaurant } \\
\text { Group }\end{array}$} & \multicolumn{5}{|c|}{ Socio-Cultural Meaning of Entrepreneurial Accounting } \\
\hline & \multirow{2}{*}{$\begin{array}{l}\text { Business Process } \\
\text { Turbulence }\end{array}$} & \multirow{2}{*}{$\begin{array}{l}\text { Togetherness } \\
\text { Intensity }\end{array}$} & \multicolumn{2}{|l|}{ Process Control } & \multirow{2}{*}{$\begin{array}{l}\text { Design of } \\
\text { entrepreneurshi } \\
\mathrm{p} \text { accounting for } \\
\text { Performance } \\
\text { Achievement }\end{array}$} \\
\hline & & & Informal Control & Formal Control & \\
\hline SPRG & $\begin{array}{l}\text { Starting from } \\
\text { scratch } \\
\text { Confronting ups } \\
\text { and downs in the } \\
\text { business process }\end{array}$ & $\begin{array}{l}\text { Team work } \\
\text { culture } \\
\text { Togetherness } \\
\text { proportion } \\
\text { with mato } \\
\text { system } \\
\text { Investor } \\
\text { involvement } \\
\text { from middle } \\
\text { class and } \\
\text { modernists. }\end{array}$ & $\begin{array}{l}\text { High Intensity of } \\
\text { the } \\
\text { Owner/Entrepre } \\
\text { neur-Director's } \\
\text { influence } \\
\text { Socio cultural } \\
\text { control } \\
\text { Unwritten norms } \\
\text { Oral culture }\end{array}$ & $\begin{array}{l}\text { High business } \\
\text { complexity } \\
\text { High formal control } \\
\text { intensity } \\
\text { High written norms } \\
\text { intensity } \\
\text { Mato-based profit } \\
\text { sharing accounting } \\
\text { More structured } \\
\text { Modern administration } \\
\text { influence }\end{array}$ & $\begin{array}{l}\text { Result of very } \\
\text { hard work } \\
\text { Focus } \\
\text { customer's } \\
\text { satisfaction } \\
\text { Maximum profit } \\
\text { gain } \\
\text { Satisfaction of } \\
\text { the employee, } \\
\text { investor and } \\
\text { owner } \\
\text { Mato-based } \\
\text { incentive } \\
\text { (personal score } \\
\text { card) }\end{array}$ \\
\hline KCPR & $\begin{array}{l}\text { Starting from a } \\
\text { scratch } \\
\text { Confronting ups } \\
\text { and downs in the } \\
\text { business process }\end{array}$ & $\begin{array}{l}\text { Team work } \\
\text { culture } \\
\text { Togetherness } \\
\text { proportion } \\
\text { with mato } \\
\text { system } \\
\text { Investor } \\
\text { involvement } \\
\text { from middle } \\
\text { class and } \\
\text { modernists. }\end{array}$ & $\begin{array}{l}\text { High Intensity of } \\
\text { the } \\
\text { Owner/Entrepre } \\
\text { neur-Director's } \\
\text { influence } \\
\text { Socio-cultural } \\
\text { control } \\
\text { Unwritten norms } \\
\text { Oral culture }\end{array}$ & $\begin{array}{l}\text { Lower business } \\
\text { complexity than that of } \\
\text { SPRG } \\
\text { Lower formal control } \\
\text { intensity than that of } \\
\text { SPRG } \\
\text { Lower written norms } \\
\text { intensity than that of } \\
\text { SPRG Mato- } \\
\text { Less complex Maring } \\
\text { based profit sharition } \\
\text { accounting } \\
\text { Traditional } \\
\text { administration }\end{array}$ & $\begin{array}{l}\text { Result of very } \\
\text { hard work } \\
\text { Focus on } \\
\text { customer's } \\
\text { satisfaction } \\
\text { Maximum profit } \\
\text { gain } \\
\text { Satisfaction of } \\
\text { the employee, } \\
\text { investor and } \\
\text { owner } \\
\text { Mato-based } \\
\text { incentive } \\
\text { (personal score } \\
\text { card) }\end{array}$ \\
\hline MRG & $\begin{array}{l}\text { Starting from a } \\
\text { scratch } \\
\text { Confronting ups } \\
\text { and downs in the } \\
\text { business process } \\
\text { Mato-based } \\
\text { incentive (personal }\end{array}$ & $\begin{array}{l}\text { Team work } \\
\text { culture } \\
\text { Togetherness } \\
\text { proportion } \\
\text { with mato } \\
\text { system } \\
\text { Absence of }\end{array}$ & $\begin{array}{l}\text { High Intensity of } \\
\text { the } \\
\text { Owner/Entrepre } \\
\text { neur-Director's } \\
\text { influence } \\
\text { Socio-cultural } \\
\text { control }\end{array}$ & $\begin{array}{l}\text { Formal control } \\
\text { Written norms } \\
\text { Far less complex } \\
\text { Mato-based profit } \\
\text { sharing accounting } \\
\text { than that of SPRG and } \\
\text { KCPR }\end{array}$ & $\begin{array}{l}\text { Result of very } \\
\text { hard work } \\
\text { Focus on } \\
\text { customer's } \\
\text { satisfaction } \\
\text { Maximum profit } \\
\text { gain }\end{array}$ \\
\hline
\end{tabular}




\begin{tabular}{|l|l|l|l|l|l|}
\hline & score card) & investors & $\begin{array}{l}\text { Unwritten norms } \\
\text { Oral culture }\end{array}$ & $\begin{array}{l}\text { Satisfaction of } \\
\text { employee } \\
\text { the } \\
\text { and owner }\end{array}$ \\
\hline PSPN & $\begin{array}{l}\text { Starting from a } \\
\text { scratch }\end{array}$ & $\begin{array}{l}\text { Very low } \\
\text { Team work } \\
\text { Absence of } \\
\text { investors }\end{array}$ & $\begin{array}{l}\text { The lowest } \\
\text { Socio-cultural } \\
\text { control } \\
\text { Oral culture } \\
\text { control } \\
\text { Memory accounting }\end{array}$ & $\begin{array}{l}\text { Fesult of very } \\
\text { Fard work } \\
\text { customer's } \\
\text { satisfaction }\end{array}$ \\
\hline
\end{tabular}

\subsection{The Construction of Entrepreneurial Accounting in SPRG}

\subsubsection{Business Process Turbulence}

SPRG was built from a scratch and experienced frequent failure. This business started from a small stall in 1972 in Central Jakarta. The management of this group has implemented profit sharing using a mato system although it has only a limited application to the owner/entrepreneur-director and the employees of the restaurant (Hanif, et. al., 2015; Hanif, 2015a; Hanif, 2015b; Hanif et. al., 2018). In its' 46 years, it has expanded to include hundreds of branches and thousands of investors and employees. Its management has persistently implement existing mato-based profit sharing systems which have been modified to keep up with the development of the business.

\subsubsection{Togetherness Intensity}

Management of the company promotes kinship systems. The relationship between the owner/entrepreneur-director and the employees does not typically follow a hierarchy. All employees works together as a collective, known as gotong royong ${ }^{1}$ a local wisdom existing in Indonesian society. The profit gained is for all and is divided periodically to all employees and owner/entrepreneur-directors by the mato system. The mato load or personal card proportionally determines the amount received. This system promotes teamwork.

On the basis of this togetherness value, the business is developed by developing cooperation with other parties to open new restaurant branches. The values of togetherness and gotong royong are maintained by the mato-based profit sharing system. Further, the system is developed to keep pace with existing circumstances. Where it was previously applied for two parties (owner/entrepreneur-director and employees), it is now used for three parties (owner/entrepreneur-director, employees and investors). This covers $50 \%$ for employees, $35 \%$ for investors, and $15 \%$ for owner/entrepreneur-directors.

Because the SPRG business has a promising prospect of high profit, a lot of parties are interested in joining this group. It has nearly 100 investors comprised of "the scholars" and educated or "office workers", and ex-officials of Indonesia. These backgrounds differ from that of the owner/entrepreneur-directors that come from a humble family and did not experience "formal education". This condition gives rise to certain consequences in the business processes including the accounting design and its control processes.

\footnotetext{
${ }^{1}$ Gotong royong is a terminology in Indonesian Language which means a culture of cooperation on the basis of sincerity
} 


\subsubsection{Process of Control}

\subsubsection{Informal Control}

Despite the fact that SPRG has turned into the largest and most successful Padang restaurant in Indonesia, the control process of the company remains dominated by the owner/entrepreneur-director through an informal social control. The owner/entrepreneur-director is inclined to rely on direct oral communication. The profit sharing accounting mato system, the culture of togetherness and local wisdom have a strong presence in SPRG in the modernization era (Hanif, 2017).

\subsubsection{Formal Control}

It is undeniable that business processes are holistically impacted as the complexity of business management increases. This includes the most important aspect being accountability. To comply with the rules of SPRG, the investors have no rights in controlling the company's operation for which the owner/entrepreneur-director is responsible. The investors are able to control their investment using the reports produced by the owner/entrepreneur-director including financial statements.

The complexity of the SPRG may be the result of the number of investors. The calculation of the portion owned by an investor is called a "finger". A man has 20 fingers in total, "1 finger" equals to $1 / 20$ (5\%), "2 fingers" equals to $2 / 20(10 \%)$, and so forth. If he or she places an investment of " 1 finger", the investor has 5\% stock of the total deposited capital. Further, 20 investors may join one another to build a new restaurant branch and make a deal to invest "1 finger".

The investors themselves affect the atmosphere of the company due to their prior experience working in a formal organization and dealing with modern administration. As the complexity of the organization increases, the owner/entrepreneur-director must adjust their leadership style. This is reflected in their entrepreneurial accounting, being the profit sharing accounting mato system, which is progressively adapted with modern administration.

\subsubsection{Design of Entrepreneurial Accounting for Performance Achievement}

Entrepreneurial accounting is designed to satisfy the interests of all stake holders have in order to encourage employees to work harder and improve their performance. A mato-based profit sharing system can be used to increase personal satisfaction as it characterises employees as partners rather than laborers. All stake holders are given a load of mato (personal score card), and the profit based on the ratio of mato is evenly divided amongst them. The workers will, in return, achieve self-satisfaction; what they earn is what they strive for. The investors will also do the same with the flow of the investment, which brings the owner/entrepreneur-director both financial and non-financial advantages. The ability of the owner/entrepreneur-director and its management to use their influence to create and implement such accounting has made SPRG grow significantly to hundreds of branches across 15 provinces in Indonesia and even overseas.

\subsection{The Construction of Entrepreneurial Accounting in KCPR}

\subsubsection{Business Process Turbulence}

Similar to SPRG, the owner/entrepreneur-director of the KCPR group has generally developed the business from scratch using trial and error, however, the business has gradually improved over time as the owner/entrepreneur-director has gained more experience. Nowadays, KCPR belongs to the middle-scale business group following the SPRG in terms of the number of employees and the amount of investment. 
KCPR is owned and managed by a group of people from Kebumen ${ }^{2}$ in Central Java. Padang restaurant is managed by people from West Sumatera as well as anyone with the right amount of passion and willingness to be a part of the business. What makes them interested in this Padang restaurant business? It is its' potential to grow and prosper in the market. In addition, these people have had an experience working in similar restaurant and are familiar with the business processes.

\subsubsection{Togetherness Intensity}

Kebumen society is community within Minangkabau ${ }^{3}$ and is where the Padang restaurant was established. The characteristics of the people are similar in many ways; they love to help each other and work together. The profit sharing system is therefore highly successful in this area. Nevertheless, some differences exist in their cultural background. Kebumen people are Javanese whilst Minangkabau people come from West Sumatera. This affects the orientation of their business culture. Kebumen people are more commonly workers and professionals whilst the Minangkabau people are well-known as merchants.

The establishment of KCPR was the result of Kebumen people with a sense of entrepreneurship. The profit sharing pattern applied in this area is similar to that of SPRG, which divides profit among three parties: owner/entrepreneur-directors, workers, and investors. The difference lies in the background of the investors. SPRG investors typically belong to the middle-upper class whilst KCPR investors predominantly belong to relatives living in Kebumen with farming backgrounds. The latter group may have more on their communal nuance, which has an impact on their control processes.

\subsubsection{Process Control}

\subsubsection{Informal Control}

Applied in a similar way, the influence of the owner/entrepreneur-directors of KCPR is achieved through an informal control known as a social process. Direct and oral communication by means of social media is regularly used in this kind of control process which is maximized by holding a monthly social gathering. There is no written rule in this process, nor a legal agreement, however, the control is effectively understood by all employees and investors. The cooperation among these parties is grown based on the togetherness of being in one community. This fosters good communication which enables control processes to run effectively. Accountability of the business is frequently conducted informally and relies on mutual trust.

\subsubsection{Formal Control}

The owner/entrepreneur-director modifies the accounting using the socio-culture of KCPR as reflected from its modified profit sharing pattern. The pattern is similar to that used by SPRG; it is applied to three parties: owners, employees and investors. The profit is calculated and shared within each 100-working-day period. However, there seems to be a difference in the number of investors between the two groups. The SPRG does not limit the number of investors and they themselves have the right to control the business through book-keeping and financial statements.

The number of investors in KCPR is, on the other hand, limited to two to three persons in order to achieve efficient operational control and improve decision making; however, one investor may invite others to join the group under his or her control. For example, three investors consisting of: Mr. A, Mr. B, and Mr. C who all have equal votes to control the restaurant may also have their own group of investors at the same time. This means that Mr. A could have 20 investors under his or her control, as could Mr. B and Mr. C.

\footnotetext{
${ }^{2}$ Kebumen is the name of a residence located in Central Java, Indonesia.

${ }^{3}$ Minangkabau is another name used to refer to West Sumatera, Indonesia. The terminology of Minangkabau is used to emphasize the culture of West Sumatera society.
} 
Further, the investors are also handled in a different way depending on their characteristics. For instance, SPRG investors come from urban people who are used to modernize management whilst KCPR investors come from farming backgrounds with limited funding.

KCPR investors are socio-culturally more communal than SPRG investors. Each investor establishes a strategy to overcome funding problems by having a group of investors (Mr. A, Mr. B, Mr. C) invite more and more investors. The owner/entrepreneur-director's own efforts may also attract new funding to meet the objective of control as the investors are only represented by 3 (three) major persons. The profit sharing accounting in KCPR organizations is also more communal and simpler in its implementation because it is not affected by modern aspects, unlike SPRG.

The investors that generally join the main investors of KCPR are their own relatives who live in Kebumen, their hometown. This creates a mutually beneficial relationship among the cooperating parties. The relatives who happen to be farmers and live in the village are likely to place their investment in town on the KCPR business. Even though each person only makes a minor investment, for example "1 finger" (5\%) as quoted from the terminology of SPRG, the total investment of Mr. A's group might reach as much as $100 \%$ once they are all pooled together. When this is added with the investment collected from the groups of Mr. B and Mr. C, these three groups have sufficient funding to open a new restaurant franchise. Thus, one franchise of KCPR can be owned by 60 persons on behalf of 3 partnerships, namely Mr. A, Mr. B, Mr. C.

\subsubsection{Design of Entrepreneurial Accounting for Performance Achievement}

The design of profit sharing accounting in KCPR is similar to that of SPRG and aims to investigate the goal congruence point of all stakeholders. Employees will work harder because they may expect higher income "at this moment." KCPR employees, like SPRG, do not receive a regular salary. What they earn is based on what they work for, in their attempt to serve quality products. This atmosphere will increase revenue and profits from which all parties earn their living. This system promotes maximum performance in both financial and non-financial sectors. The success of KCPR is largely due to word of mouth.

\subsection{The Construction of Entrepreneurial Accounting in MRG}

\subsubsection{Business Process Turbulence}

Similar to the previous groups, MRG started its business from a small Padang restaurant. The owner/entrepreneur-director was previously an experienced employee working in a formal sector. He has worked in a bank for 10 years and is a university graduate. He realized that being an entrepreneur requires bravery to take risks beyond the expectation of earning limitless income. MRG has been on its journey for almost 15 years has spread over 6 branches. The owner/entrepreneur-director is not willing to involve external investors. Otherwise, the business process in MRG is not too dissimilar from that of SPRG and KCPR.

\subsubsection{Togetherness Intensity}

The expansion of MRG is managed by personal capital and profits of the business, which implicates entrepreneurial accounting. The profit sharing system applies to only two parties (owner/entrepreneurdirector and employees) as there are no external investors. Its accounting design is simpler than that of SPRG and KCPR although its employees are treated relatively the same as those of the latter groups. 


\subsubsection{Process Control}

\subsubsection{Informal Control}

The owner/entrepreneur-director has a high degree of influence on the policies of the restaurant which is managed and owned by an ex-banker who was brought up in Minangkabau culture. In light of the business scale, each outlet of MRG resembles KCPR in terms of the number of employees and the amount of investment. Layout, neatness, and cleanliness are the primary concerns in addition to good tasting food, which is the focus of the restaurant. Since he has worked in a modern sector, the owner/entrepreneur-director of MRG manages the restaurant with more organisation and discipline than SPRG and KCPR.

\subsubsection{Formal Control}

The delegation of work and operational control within MRG is marginally distinguished from that of SPRG and KCPR. Profit sharing is calculated using a one-month-period. This implicates MRG profit sharing accounting despite the fact that the share covers the same portion of 50:50; evenly between the employees and the owner/entrepreneur-director. Therefore, the employees' total earnings is divided for each individuals based on their particular load or mato. The mato level that each employee has differs according to their contribution.

\subsubsection{Design of Entrepreneurial Accounting for Performance Achievement}

Profit sharing accounting is designed to protect the interests of both owner/entrepreneur-directors and employees. The timeliness for submitting the profit and loss statements has an effect on the improvement of the company. What needs improving in the previous month is reviewed and quickly followed up for better performance in the following period. The measurement and reporting of the finances of the company upon the profit sharing is conducted within a one-month period instead of a three-month period adopted by SPRG or a 100-day period adopted by KCPR. This scheme enhances satisfaction for both the owner/entrepreneurdirector and employees.

\subsection{The Construction of Entrepreneurial Accounting in PSPN}

\subsubsection{Business Process Turbulence}

PSPN belongs to the group of KCPR; however, the actor only manages 1 (one) outlet because he has decided not to allow other parties to invest. The owner of PSPN has experienced many conflicts with his cooperation scheme. The oral communication has been dominantly practiced upon all kinds of the cooperation and there is no order of conduct for sufficient administration.

A sense of entrepreneurship closely relates to an ability to handle risk and failure. When we fail, we must try again. This sense does not seem to flourish in the heart of PSPN, unlike in SPRG, KCPR and MRG.

\subsubsection{Togetherness Intensity}

PSPN focusses on one outlet managed by his wife and one assistant. There is no profit sharing system among the employees although the business does make a profit. As a consequence, the business does not develop in the same way as SPRG, KCPR, and MRG. Thus, it is evident that a sense of entrepreneurship is required for the expansion of a business i.e. bravery to take risks, as well as high social skill. 


\subsubsection{Process Control}

PSPN has a very low level of either informal or formal control because it has no job delegation. In addition, PSPN management has a very simple financial administration which depends only on memory accounting; transactions are not well-listed.

\subsubsection{Design of Entrepreneurship Accounting for Performance Achievement}

PSPN requires a special design for its' accounting. Its performance is focused on increasing customer satisfaction through the quality of the food, service and competitive prices. This business has in fact been quite successful despite the absence of any expansion.

\subsection{Summary of The Previous Discussion of Four Restaurant Groups for The Construction of Local Entrepreneurial Accounting}

Based on the previous discussion, it can be concluded that the construction of entrepreneurial accounting has the following characteristics:

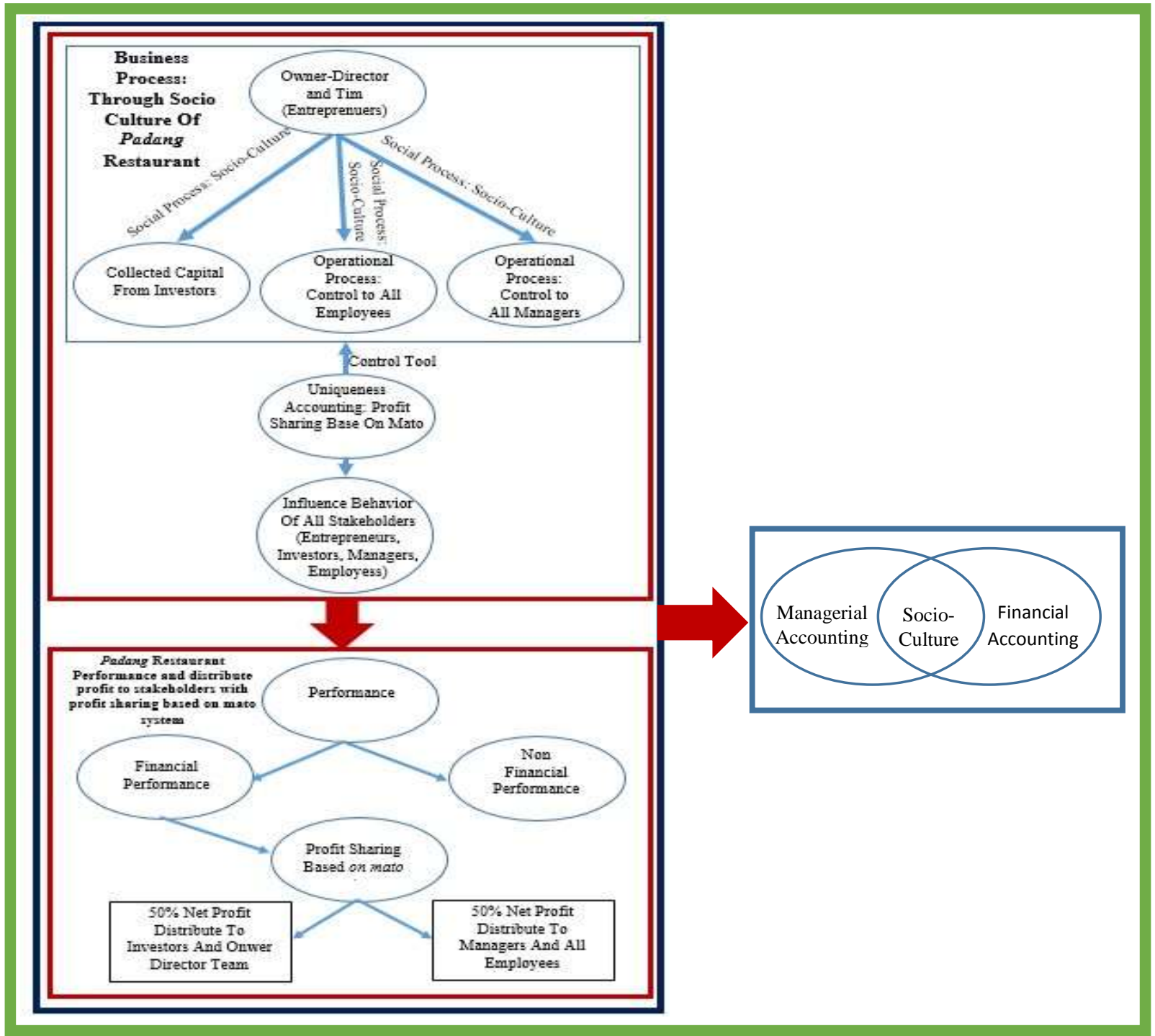

Figure 1. The Construction of Entrepreneurial Accounting

Global J. Bus. Soc. Sci. Review 7 (2) $104-117$ (2019) 
Figure 1. The Construction of Entrepreneurial Accounting shows that it aims to help the ownerentrepreneur-director realize the function of entrepreneurs to increase the financial and non-financial performance of the company. The observations of the four owners/entrepreneurs-directors representing the four business groups of Padang Restaurant portrays that the development of entrepreneurial accounting is contextual and localistic in nature. The owners/entrepreneurs-directors have ingenuity as businessmen and modify the entrepreneurial accounting by adjusting the profit sharing scheme according to the socio-cultural conditions of the company. Entrepreneurial accounting based on profit sharing using a mato system has therefore colored the accounting practices to meet the internal needs of a company (management accounting).

\section{Discussion}

Management accounting is one branch of accounting encompasses many topics including, but not limited to: behaviors in an organization, strategic management, cost and benefit analysis, information about accounting for internal management in a company, human resources management, and others (Anthony \& Govindarajan, 2007; Hilton, 2008; Hansen \& Mowen, 2005; Blocher et. al., 2013). Thus, there is no specific study that addresses entrepreneurial accounting. Further, some research examining the relationship between entrepreneurship and accounting has emerged, such as a study by Collier (2005) which found that entrepreneurial control can be used to explain that socio-culture is effective to manage and control human resources.

The present research supports the findings of Collier's research. The owner/entrepreneur-director of a Padang restaurant can ingeniously read the socio-culture of the organization and respond to it by adapting it's accounting design. The socio-culture of Padang restaurant emphasizes the values of togetherness, teamwork, mutual trust, and a sense of belonging. The owner/entrepreneur-director having read the socio-culture of the organization determines the business management using a mato-based profit sharing system. When the socioculture develops or changes, the owner/entrepreneur-director will modify the accounting design so that it will remain a substantially mato-based profit sharing system. The so-called profit sharing accounting using mato system is in the realm of either management accounting (Hanif et. al., 2015; Hanif, 2015b; Hanif et. al., 2018) or financial accounting (Hanif, 2015a, 2017).

Entrepreneurial accounting that addresses management accounting can be portrayed in the management of control processes that are adapted to the employees' socio-culture. This cultural nuance is dominated with togetherness, putting trust and openness forward as reflected from the selected accounting model employed in the management. Selecting informal ways to control a company's operations is recommended in Collier (2005).

From a modern organizational viewpoint, management control using formal budgeting can increase a company's financial control and hence it's financial performance. Otley (1978) notes that a well-managed budget can increase financial performance. Unfortunately, the budget is not accounted for in the management of a Padang restaurant; instead it uses a mato-based profit sharing system (Hanif et. al., 2015; Hanif, 2015b; Hanif et. al., 2018). The profit gained and shared based on mato system promotes the managers' and employees' performance although monthly-based budgeting and incentive scheme do not apply.

The entrepreneurial accounting also includes the sphere of financial accounting in particular as an accountability tool of the company toward stake holders and is based on profit sharing with a mato system (Hanif et. al., 2015; Hanif, 2015a, 2017). Thus, this sort of accounting serves as a means of accountability of the company toward its' investors and employees, in addition to serving as a tax guideline.

To maintain the accountability of the company toward the employees in each restaurant franchise, $50 \%$ of the net profit is shared for the owner/entrepreneur-director and reported in the income statement. Since this has to be strictly accounted for, it must be free from unlawful interference with economic and other interest. Accounting as a means of accountability plays an important role in fostering mutual trust and to maintain working spirit. Accounting practices are intended to be based on fairness and transparency. Having had the

Global J. Bus. Soc. Sci. Review 7 (2) $104-117$ (2019) 
policy, the three restaurant groups implementing mato-based profit sharing system will grow and expand rapidly, unlike the PSPN group which does not apply the policy. PSPN remains stagnant and has never been better.

\section{Conclusion}

There are four cultural meanings of entrepreneurial accounting for the four Padang Restaurant groups, namely (1) business process turbulence; (2) togetherness intensity; (3) informal control processes; and (4) formal control processes. Despite the fact that all of the restaurants have similar cultural themes, the elements embedded in each theme are different which give rise to certain adjustment in the design of entrepreneurial accounting based on a profit sharing system.

Entrepreneurial accounting is a skill that an owner/entrepreneur-director must have to conduct a successful business. The business opportunity is not to discover but to create with full awareness . The entrepreneur-director must realize that its' accounting methods must be adjusted according to the development of the socio-culture of the business.

The success achieved by the entrepreneur-director of SPRG and KCPR is due to their ability to create a business opportunity for restaurant development through innovation such as collecting capital from other parties who are willing to invest in the business. This innovation is in fact able to accelerate the growth of the restaurant. SPRG started from a small stall and has existed for 45 years. It now has over 150 branches with thousands of employees and branches spreading over 15 provinces in Indonesia and overseas. The owner/entrepreneur-director is able to read the socio-cultural development of the business group and create partnership accounting in accordance with the socio-cultural conditions.

Similarly, the owner/entrepreneur-director of KCPR has created a business opportunity and modified the accounting practices accordingly. KCPR is more unique than SPRG in terms of managing the investors. The number of investors in SPRG required to open a new branch is unlimited whilst the number of investors required in KCPR is limited to a maximum of three persons who have the rights to collect funds from local people in Kebumen. MRG group has also developed quite successfully with its profit sharing system although it is only applied between the owner/entrepreneur-director and employees instead of investors. This represents the main difference in the concept of entrepreneurship implemented among MRG, SPRG, and KCPR groups. MRG business does not grow as fast as the others.

The decision to operate a profit sharing scheme is therefore smart for these business groups. Profit sharing is also a form of social control which seeks to achieve optimal congruence between the company and the employees as well as to conceive a sense of belonging. The PSPN group does not compare to the SPRG, KCPR and MRG groups as it has minimal sense of entrepreneurship and is slower to develop than its counterparts.

However, the results of exploring the cultural meaning of entrepreneurial accounting for each Padang restaurant group can be formulized and integrated into one construction of entrepreneurial accounting coloured with the unique socio-culture of the Padang restaurant as illustrated in Figure 1. Entrepreneurial accounting enables owner/entrepreneur-directors to execute work programs with a view to achieving the company's goals, that is, to enhance performance either financially (multiplying company's wealth) or nonfinancially.

\section{References}

Anthony, R. N. and Govindarajan, V. (2007). Management Control Systems (Vol. 12). New York, NY: McGraw-Hill. https://doi.org/10.1108/CG-05-2017-0105.

Ardichvili, A., Cardozo, R., and Ray, S. (2003). A Theory of Entrepreneurial Opportunity Identification and Development. Journal of Business Venturing, 18(1), 105-123. https://doi.org/10.1016/S0883-9026(01)00068-4. 
Baron, R. A. (1998). Cognitive mechanisms in entrepreneurship: Why and when enterpreneurs think differently than other people. Journal of Business venturing, 13(4), 275-294. https://doi.org/https://doi.org/10.1016/S08839026(97)00031-1

Bender, A., Hutchins, E., \& Medin, D. (2010). Anthropology in cognitive science. Topics in Cognitive Science, 2(3), 374-385. https://doi.org/10.1111/j.1756-8765.2010.01082.X

Blocher, E. J., Stout, D. E., Juras, P. E., \& Cokins, G. (2013). Cost Management: A Stategic Emphasis (7th ed.). Mc Graw Hill. https://www.abebooks.com/9780077733773/Cost-Management-Strategic-Emphasis-Edward0077733770/plp

Collier, P. M. (2005). Entrepreneurial control and the construction of a relevant accounting. Management Accounting Research, 16(3), 321-339. https://doi.org/https://doi.org/10.1016/j.mar.2005.06.007

D'Andrade, R. G. (1981). The cultural part of cognition. Cognitive science, 5(3), 179-195. https://doi.org/10.1016/S0364-0213 (81)80012-2

Djankov, S., Qian, Y., Roland, G., \& Zhuravskaya, E. (2006). Who are China's entrepreneurs?. American Economic Review, 96(2), 348-352. https://doi.org/10.1257/000282806777212387

Ireland, R. D., \& Webb, J. W. (2007). Strategic entrepreneurship: Creating competitive advantage through streams of innovation. Business horizons, 50(1), 49-59.https://doi.org/https://doi.org/10.1016/j.bushor.2006.06.002

Efferin, S., \& Hopper, T. (2007). Management control, culture and ethnicity in a Chinese Indonesian company. Accounting, Organizations and Society, 32(3), 223-262. https://doi.org/https://doi.org/10.1016/j.aos.2006.03.009

Hanif. (2015a). Introducing Mato Based Profit-Sharing Accounting and its Synergy with Cooperative and Sharia. Procedia - Social and Behavioural Sciences, $211, \quad 223-1230$. https://doi.org/http://dx.doi.org/10.1016/j.sbspro.2015.11.163

Hanif. (2015b). Management Control System Design: An Interpretive Ethnography. Procedia - Social and Behavioral Sciences, 211, 119-126. https://doi.org/http://dx.doi.org/10.1016/j.sbspro.2015.11.018

Hanif. (2015c). The Meaning of Behind Entrepreneurship Accounting Based on Local Wisdom. Jurnal Akuntansi, 4, 120. http://gatrenterprise.com/GATRJournals/a_critical_analysis_of_startup_business_in_indonesia.html

Hanif. (2017). (Re) Construction of Financial Accounting of Profit Sharing Based on Mato System. Akuntansi Multiparadigma, 8(2), 1-15. Retrieved from http://jamal.ub.ac.id/index.php/jamal/article/view/505

Hanif, H., Rakhman, A., \& Nurkholis, M. (2018). New Productivity Concept Based on Local Wisdom: Lessons from Indonesia. J. Mgt. Mkt. Review, 3(3), 96-103. https://doi.org/10.31227/osf.io/82snb

Hanif, Ludigdo, U., Rahman, A. F., \& Baridwan, Z. (2015). Profit Sharing Accounting Based on Mato System: The Ethnography of Padang Restaurant Business. Jakarta: Mitra Wacana Media. https://doi.org/10.1016/j.sbspro.2015.11.163

Hansen, D. R., \& Mowen, M. M. (2005). Management Accounting (7th ed.). Singapore: Thomson South-Western. https://www.abebooks.com/Management-Accounting-7th-Hansen-Don-Mowen/883111435/bd

Hayes, D. C. (2014). Contingency Managerial Theory of Accounting, 52(1), 22-39. DOI: 10.12691/jbms-1-5-3

Hilton, R. w. (2008). Managerial Accounting: Creating Value in a Dynamic Business Enviromental (7th ed.). Mc Graw Hill. https://lib.ugent.be/catalog/rug01:001191406

Jankov, B. S. I. D., Oland, R. R., Ian, Y. I. Q., \& Huravskaya, E. K. Z. (2006). Who Are China's Entrepreneurs? https://eml.berkeley.edu/ groland/pubs/AERChina.pdf

Kets de Vries, M. F. (1996). The anatomy of the entrepreneur: Clinical observations. Human relations, 49(7), 853-883. https://doi.org/10.1177/001872679604900701

Michelacci, C., \& Silva, O. (2007). Why so many local entrepreneurs?. The Review of Economics and Statistics, 89(4), 615-633.https://doi.org/10.1162/rest.89.4.615

Minniti, M., \& Lévesque, M. (2008). Recent developments in the economics of entrepreneurship. https://doi.org/10.1016/j.jbusvent.2008.01.001

Otley, D. T. (1978). Budget use and managerial performance. Journal of accounting research, 122-149. DOI: $10.2307 / 2490414$

Sexton, D. L., \& Bowman, N. (1985). The entrepreneur: A capable executive and more. Journal of business venturing, 1(1), 129-140. DOI: 10.1016/0883-9026(85)90012-6

Spradley, James P. (James Phillip) (1979). The Ethnographic Interview. Harcourt Brace Jovanovich College Publishers, Fort Worth, Tex. https://trove.nla.gov.au/work/8617832?selectedversion=NBD1314278

Toms, S. (2006). Accounting for entrepreneurship: a knowledge-based view of the firm. Critical Perspectives on Accounting, 17(2-3), 336-357.https://doi.org/https://doi.org/10.1016/j.cpa.2003.08.012 